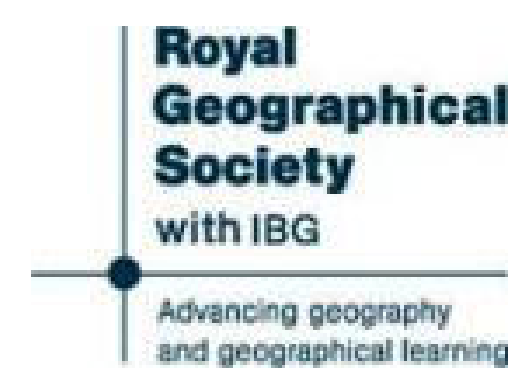

Notes on Western Madagascar and the Antinosi Country Author(s): J. T. Last

Source: The Geographical Journal, Vol. 6, No. 3 (Sep., 1895), pp. 227-252

Published by: The Royal Geographical Society (with the Institute of British Geographers)

Stable URL: http://www.jstor.org/stable/1774249

Accessed: 15/12/2014 04:45

Your use of the JSTOR archive indicates your acceptance of the Terms \& Conditions of Use, available at

http://www.jstor.org/page/info/about/policies/terms.jsp

JSTOR is a not-for-profit service that helps scholars, researchers, and students discover, use, and build upon a wide range of content in a trusted digital archive. We use information technology and tools to increase productivity and facilitate new forms of scholarship. For more information about JSTOR, please contact support@jstor.org. 
Note.-A few photographs of Borgu by Mr. Mottram, and of various parts of the Niger by Dr. Crosse-who for some nine years has been the senior medical officer in the Niger Company's service, and has shown a devotion to his work which is the theme of every one who has ever visited the Territories-were shown on the screen.

\section{NOTES ON WESTERN MADAGASCAR AND THE ANTINOSI COUNTRY.*}

By J. T. LAST.

IN this paper I wish to put on record some of the chief points of interest connected with my journeys and explorations along the west coast of Madagascar, and also some account of the south-central districts, inhabited by the Antinosi immigrants from the country near Fort Dauphin, on the south-east coast. The primary object of my expedition was to make collections of Lepidoptera, to which I added that of collecting other objects of natural history, and of obtaining general information about the country, people, and places as circumstances permitted.

Sometime previous to my visit to Madagascar I had been engaged in similar pursuits in East Africa. Leaving East Africa, I went by mail to Zanzibar, where I made a few collections in natural history, and also preparations for a lengthened stay in Madagascar.

On July 2, 1889, I embarked, with a party of six Zanzibar men, on board the French mail steamer Amazone. In three days we had reached the rocky mountain mass of Mayotte, one of the Comoro islands, and on the next day we dropped anchor at Nosi-bé. The island of Nosi-be is situated off the north-west coast of Madagascar, a few miles from the mainland, in about long. $46^{\circ} 15^{\prime} \mathrm{E}$. and lat. $13^{\circ} 20^{\prime} \mathrm{S}$. It is some 15 miles long between north and south points, and about 10 miles in extreme width, and forms part of the eastern side of Pásindáva Bay. The extinct craters show the volcanic nature of the island. Of these there are several, some in perfect form, especially one a little to the north of the town of Hellville ; the cup-like sides of this is covered with a thick forest, and there is a deep lake at the bottom. In the south part of the island rises the high mountain mass of Luku-bé. This is covered with a fine forest of magnificent trees, palms, bamboos, and other growths. The soil of the island is fairly good, and sugarcane has been largely cultivated for the manufacture of sugar and rum ; but, owing to the heavy taxes and the difficulties of getting labour, many of the proprietors find it most difficult to make their business a paying concern. The island was formerly in the hands of the Sakalava tribe of Malagasy, who, to avoid falling into the hands of the Hovas, sought the help of the French at Bourbon, and in 1840, placed themselves and their country in their hands. The next year the French took formal possession of Nosi-bé, and have held it ever since.

* Maps, p. 300. The coast-line has been taken from the latest Admiralty chart. 
Hellville, the chief town in Nosi-bé, and the seat of the French government in the district, is built on a point on the south side of the island. The main street is occupied by the official buildings and a few shops. The rest of the town is occupied by a mixed population of various Malagasy tribes-Betsimisarana, Sakalava, Hova, and others ; with these there are also a number of Makuas from Africa, Swahilis from Zanzibar, and Antilotis from the Comoro islands. The government buildings and principal houses of the town are built of stone, some few of boards; the others are all of light material, chiefly the leaf stalks and fronds of the various palms which grow about the country. These latter buildings are very inflammable, and it is no uncommon thing to see the whole or greater part of a town destroyed in one blaze.

The rather important town of Máradúka (many markets) lies in a small bay a little to the south-east of Hellville. This place is inhabited almost entirely by Hindi traders, Makuas, and other Swahili-speaking people. It is a very dirty hole, but a considerable amount of business is done here, with the people of the mainland, in hides, rubber, ebony, and other things.

Nosi-bé can scarcely be considered a healthy place, especially about Hellville, where the back part of the town is built on the banks of a wide, steaming, muddy creek. The French have built here a strong pier and landing-place, and extensive coal-sheds for the use of their men-of-war, which are frequently here; and also the mail steamers of the Messageries Maritimes, which call here every month.

I was engaged for about two months collecting in Nosi-bé and the adjacent islands of Ambári-vátu and Táni-kéli. Ambári-vátu is a conical-shaped hill of about 2000 feet high, rising out of Pásindáva Bay, a short distance to the south of Nosi-bé. It is well wooded all over, but very rocky, quite unsuitable for cultivating anything. There are a few small Sakalava villages near the beach, but the natives depend more on their fishing to supply their wants than on anything they can grow. Lately the crown of the hill has been cleared, and the French governor of Nosi-bé has built there a kind of country house and sanatorium.

Táni-kéli is a much smaller and less elevated island nearly in the middle of Pásindáva Bay. It is of undoubted volcanic formation, and its beautiful vegetation of palms, ferns, orchids, and other plants, are well worthy of a visit from any botanist who may happen to be in the neighbourhood. At the west end of the island there is a large colony of bats, a species of pteropus or fox bat. These all hang sleeping during the day; as the evening comes on they all stream off to the adjacent country in search of food. The morning finds them all back again at the same trees; nor, even if they are disturbed, do they quickly forsake their old haunts and seek fresh ones.

It was now time that I should begin to explore and collect about on 
the mainland; but before doing so it was necessary I should go to Anórontsánga and see the governor-general Rakotovau, and obtain from him letters of introduction or passes to all the subordinate governors and officers in his district. This is a large tract of country extending from the river Andránu-bé a little to the south-west of Nosi-bé, to the river Máivaránu, in about lat. $14^{\circ} 35^{\prime} \mathrm{S}$. This includes more than 100 miles of coast, and inland there is no definite boundary. The whole of the district, excepting some few flat places near the coast, is exceedingly hilly, and in some parts lofty mountains raise their heads to a height of 6000 or 7000 feet. It was my wish to visit as much as possible of this district, and to do this it was necessary that I should have at least the good-will of the Hovas, even if I did not get any actual help from them. To secure this it was necessary I should see Rakotovau, the governorgeneral at Anórontsánga.

Anórontsánga occupies an important situation in Rafála Bay, at a distance of some 45 miles or more to the south-west of Nosi-bé. It can be reached from Nosi-bé by two routes-ore by boat or canoe to Ambúdimadíru, a town at the south extremity of Pásindáva Bay, and the rest of the journey overland; the other way is to go either by large canoe or boat all the distance by water, steering across Pásindáva Bay to Vávatúbe and Kivínji Rock, and then down the coast to Rafála Bay. I decided to go all the way by water, and hired a boat for that purpose. The journey generally takes two days, but, owing to bad winds, the first day's sail took us to a village, Márakúhu, on the west side of Pásindáva Bay, and there we had to anchor. The wind was dead against us. We went ashore, and were made welcome by the natives, who are chiefly Sakalavas, a few Makuas and Antiloti people living with them. A Sakalava queen, Benu, ruled over this district and surrounding country at the time of my visit, but since then it has been acquired by the Hovas, without fighting, but by a little stratagem on the part of Rakotovau. I was told that he, travelling with a large party of men and attendants, professed that he was on a kind of state visit to Queen Benu. Suddenly appearing on the high land above the queen's village, he demanded submission on the part of herself and all her people, or he would blow the place to pieces. He had made a kind of wooden cannon out of a log of wood, and with it so terrified the Sakalavas that they submitted without a shot being fired.

Leaving Márakúhu the next morning, we managed to reach Vávatúbe, and had to anchor. The following morning we had a fine, fair breeze, and quickly rounded Kivínji Rock, passing the islands of Bérávi and Ránza; thence a fine sail along the coast, and we reached Anórontsánga about three o'clock in the afternoon. This is the most important Hova town on the west coast, between Cape Amber, on Búbaómbe, and Mujangá. Anórontsánga is really two towns, the coast town inhabited cliefly by Sakalavas, Makuas, and Swahili-speaking people, with a few Hovas. 
Here there is a meat market, a few Hindi stores, Hova rum-shops, and a building used as a church and school. The other part, or town, is a mile or more inland, on the top of a high hill. Here is the residence of the governor-general and other officials, and the place is inhabited exclusively by Hovas. There is a large building used as a school and church, also the usual number of rum-shops and petty-dealers' places.

My first business on landing was to hire a small house, as I intended to remain some few days in the place. After I had done this, and put things in order, I sent a notice of my arrival to the governor-general, and at the appointed time went up to pay the customary visit. Introduced by a Norwegian gentleman, Mr. N. O. Handerwick, who has been many years in the country, and is a personal friend of the governorgeneral's, I was well received by the Hovas; and when I had stated the object of my visit to the place, the governor-general promised to give me all the necessary passes, and whatever assistance lay in his power.

After the formal part of the visit was over, the governor-general invited us to his private room to take some refreshment, and by his pleasant conversation and questions showed that he took a great interest in the affairs of other nations, and also in my work of collecting. $\mathrm{He}$ could hardly understand why people should spend their money and time in simply collecting a few insects and birds.

After this we retired, and shortly after we reached our house, the usual present of food was sent down by the governor. It is the custom, and by order of the queen, that all European strangers, arriving at any Hova station, shall be given a present of food, as soon as they make their presence known. It generally consists of rice, fowls, ducks and eggs. Rakotovau was especially liberal to us, sending us joints of beef as well as the usual present.

The next day Mr. Handerwick and I went by invitation to meet the governor-general and his officers at dinner in the Ruva. The "Ruva" is the fortified residence of the governor. We were most kindly received, and after dinner the governor gave me the passes and letters he had promised me on the previous day, adding that if I should require other passes, or belp in any other way, it would be his pleasure to assist as far as he was able.

Judging from my knowledge of him during nearly five years' residence in Madagascar, I have every reason to believe he acted fully up to his promises, and it is with the greatest pleasure $I$ bear testimony to the high character of Rakotovau, 14 ${ }^{\text {vtz }}$, D.P.M., Governor-General of Anórontsánga and its dependencies. In all my dealings with him, I found him to be a good man and honest; of the strictest integrity, a lover of justice, ever ready to assist any foreigner, whether trader or traveller, who will be honest with him, and yet he never forgets his position or duty to his own state and country.

After the introductory visits to the governor, I remained several 
days collecting in the coconut plantations and surrounding country, not so much for the collections, but rather that the governor and I might become better acquainted with each other. This was accomplished by an interchange of visits, and a friendship was formed which I continue to value.

Having secured the necessary papers and means, I began a series of journeys to the more distant parts of the district, governed by Rakotovau. The space at my disposal will not allow me to give a detailed account of each of these journeys; I can only here refer to the more important points of interest connected with the country and people.

The three chief journeys I made were-one to the headwaters of the Sámbiránu river; the second took me to the sources of the Manúnguárivu river; and the third, from Andránumaláza through the Ambalíha forest to Békulúsi Hill, which I ascended, and then to Anórontsánga by way of Ankarámi. The Sámbiránu river takes its rise among the mountains some 60 miles inland, a little to the south-east of the longitude of Nosi-bé, and empties itself into the sea near the south end of Pásindáva Bay. Excepting the rather extensive tract of flat country near the coast, the whole of the country through which the Sámbiránu and its tributaries flow is very hilly, and in some parts quite mountainous. The part of the river near the coast is very wide, and, during the dry season, shallow, so that then only boats of a light draught and canoes can be used on it; but during the rains the river is flooded, and boats of 5 or 6 feet draught can be taken a long way up. The principal tributaries of the Sámbiránu are the Ruáména on the right bank, and the Mánambúru and Mbáhatra on the left. These are fed by many considerable affluents, which receive all the streams and torrents from the neighbouring mountains.

The whole of the country drained by the Sámbiránu is very fertile. The lowland near the coast is one large garden, where Indian corn, millet, beans, semsem, potatoes, cassava, and pumpkins are produced in abundance. Of fruit trees every village has its mangoes, guavas, bananas, and others; while fine pine-apples are raised in the garden or near the house. Inland, along the watercourses, and on the mountain slopes, the soil is most productive, and it is one of the most prolific as well as the most extensive rice-growing districts in North Madagascar. During the dry season the minor branches of this river are very shallow, so that their beds are often used as roads between distant villages. Generally there is a path alongside the stream, but people prefer to walk in the watercourse, especially if the pathway in the forest is damp, because of the troublesome leeches. These are most voracious and rapid in attack. The native, who invariably goes about with bare legs and feet, is especially subject to their attacks, and therefore prefers to travel by the river-bed. When obliged to pass through a piece of forest where these pests exist, he arms himself with a piece of moistened tobacco tied 
in some rag to the end of a stick. Leeches have a great dislike to tobacco, and a slight touch from the tobacco-stick causes them to drop at once; otherwise they are somewhat difficult to remove until they are quite gorged, and then they drop off. The native would not attempt to pull it off; but if he had not any tobacco, he would give the leech a sharp slap, and then it would fall off.

In the Sámbiránu and all its tributaries, crocodiles abound, especially in the Rúaména ; there are also several species of fish in good numbers. The natives catch these in large baskets, but do not seem to know how to use the rod and line.

Up the Rúaména branch, about five miles from its junction with the Sámbiránu, there are four or more very hot springs of water. Two of these rise from among the rocks on the right bank of the river, and make a deposit of a kind of salt all around. This is not eaten by the natives, but they drink the water as a remedy for certain diseases, and the country doctors highly recommend its use. In the middle of the bed of the river there is a huge heap of rocky boulders piled together, and here again there are some more hot-water springs. This place is held sacred by the natives, who have adorned the rocks with poles and flags of red and white cloth. They cannot account for the fact that the springs of water are hot, so they feel there must be something supernatural about the place, and therefore it is a fit and proper place for them to present their offerings and make their prayers. There seems to be a line of these hot springs, which extend from the right bank of the Rúaména, across the country, in a westerly direction to the left bank of the Sámbiránu, where there are a number of small springs of very hot water, and the ground all around is covered with a kind of salt.

The whole of this hilly district was once covered with a dense forest. A great part of this, especially alongside the watercourses, has been cleared away, and the ground utilized as rice-gardens. Every year new tracts are felled and burnt, and new gardens made. In time, the hills will be quite denuded of forest, and the result will be a dry and barren country.

I remained in this district of the Sámbiránu some three months, making various collections. During this time I travelled about from village to village, and was always received with the greatest kindness by the natives; and I ever found them ready to help me, by supplying guides and in other ways. Food was always plentiful. A hungry stranger would never need to leave a village; he would at all times be welcome to such as the natives had, or, if he preferred to buy, he could do so at a reasonable price. In travelling, I passed but few villages without being given something-a bowl of rice, or a fowl, or both; and whenever I slept in a village, the customary gift of food was always presented.

When I had finished my work on the Sámbiránu I went to Nosi-bé, 
and shipped my collections home. After a few days' rest, I again proceeded to the mainland to resume my work.

The Manúnguárivu river rises in the lofty group of mountains lying south-east of Ankarámi. This town is situated one day's march inland from Ambúdimadíru, or two days' march in easy stages from Anórontsánga. Both roads are very rough; that from Ambúdimadíru especially so. It is seldom one has such a succession of deep valleys to cross or steep ascents to climb. The whole country along the line of march is. very hilly, and covered with a thick forest. Here and there a Sakalava village is seen, partly hidden away in some valley, and others crowning some hilltop. Around these the forest has been cleared away for a considerable distance. Here the natives make their small gardens of potatoes, cassava, and a few other vegetables. The rice-grounds are generally some little distance from the village. Streams and mountain torrents flow in all directions, and lend themselves easily to the work of irrigation, which is necessary for the drier parts of the country.

The Anórontsánga road, though rough, leads over a more open country ; it is less hilly and less thickly wooded; there are more villages and much more country cultivated. Three or four considerable streams are passed on the route, and at one of these, attached to the rocks in its bed, I found some splendid oysters of a large size. There are three kinds of oysters about the sea-coast and in some of the rivers of north-west Madagascar. The small oyster, which at low water may frequently be seen in great numbers; there is a kind of pearl oyster, which is only found at a distance from the beach and in somewhat deep water; the third is a still larger kind, only found attached to the rocks in freshwater rivers-the inside of the shell is much darker than that of the pearl oyster found in the salt water. Leaving Ankárami, we passed round the western foot of a lofty mass of hills, and in two hours reached the Manúnguárivu river. On both banks there are a number of villages and extensive gardens. Here we rested for a while, and then proceeding further up the river, camped in a village on the left bank, and made it our head-quarters whilst in the district. The chief of the village, a Betsimisaraka, was very kind, and insisted on my using his house, the best in the village, until I had finished collecting in the neighbourhood.

During the two months I spent in this district I examined almost. every stream and rivulet forming the headwaters of the Manúnguárivu. The two main branches each drain an enormous crater-like basin. That on the right bank is formed of hills some 3000 feet or more high, and encloses a cup-like hollow quite three miles in diameter. Its sides are well wooded, and numerous streams descend from all parts, to meet at the bottom, where they form a considerable river, which flows out through a large gap on the south-west side of the hollow, and runs on to the Manúnguárivu. In this huge hollow there are several villages inhabited 


\section{NOTES ON WESTERN MADAGASCAR AND THE ANTINOSI COUNTRY.}

by Sakalavas, who have cleared away large tracts of forest, on which they raise rice in abundance and sugar-cane grows luxuriantly.

The principal affluent on the left bank is fed by streams which meet together in a much larger crater-like formation than that just described. The mountain-sides rise to a height of some 6000 feet or more, and they enclose a hollow of from 10 to 12 miles in diameter. There is a large break on the north-east side by which the waters escape, and, flowing round to the north-west, enter the Manúnguárivu. The whole of the basin and the mountains on all sides are covered with a densely thick forest of fine trees, rubber-vines, and other creepers, bamboos, palms, and undergrowths. This extensive hollow is uninhabited except by the wild boar-fusa (Cryptoprocta ferox), several species of lemuroids, and some smaller forms of animal life. The natives prefer to live along the banks of the river, where they have a much more open country, especially lower down and outside the mountain mass, where there are large tracts of flat country well adapted to the cultivation of both rice and sugar-cane. This latter article is in great demand with the natives, who use it extensively in the manufacture of rum as well as a common article of food. After leaving the mountains, the Manúnguárivu flows in a south-west direction, joins with the Andránumaláza and empties itself into Radáma Bay. Excepting in the wet season the river is very shallow, and can only be navigated by canoes and boats of very light draught.

When I left this district I went by road to Anórontsánga. The French mail steamers used to call at this place in those days, so I was able to ship my collections home. Afterwards I undertook another journey from Anórontsánga to Andránumaláza, and thence through the Ambalíka forest to Békulúsi, and back to Anórontsánga by way of Ankarámi and Bézávuna. We went in a hired boat from Anórontsánga to Andránumaláza. We had hoped to reach the place in one day, but soon after entering Radáma Bay we stuck on a mudbank, and as the tide was running out, we had to remain there till it rose again. I need hardly describe the discomforts of such a position; any one who has been unfortunate enough to have to spend an evening in or near a mangrove swamp swarming with mosquitoes, can form some idea of our situation. The next morning we reached Anđránumaláza, presented our passes and proceeded on our way. This took us to the left bank of the Manúnguárivu river, and towards evening we camped just under the south side of a remarkable hill, named Anguruni. This is an isolated mass, and in the distance has the appearance of a huge building raised in terraces. The next morning we went on. After passing through some forest we came to the villages of Anúnuláva. We rested here for some time, and then followed a path which took us over a rough forest country, and after descending a narrow precipitous spur of the hills, we arrived in the Ambalíha valley. Villages are 
scattered all about the valley, and a good-sized river passes through its length, and goes on to join the Andránumaláza. River, valley, and villages all take the name of Ambalíha from the fact that "valiha" (bamboos) are the most prominent feature in the vegetation round about.

The villages are inhabited entirely by Sakalavas, who were very civil to us, giving us the information we wanted and some sugar-cane into the bargain. As we proceeded up the valley, we came to a village quite deserted. The people were all away in their distant plantations, and would not return for a month or more. We camped here for the night, and the next morning resumed our march, following the path which took us over the hills, till we came to a large tract of cleared ground land and two villages. From this place we could find no trace of a path going east. The natives insisted that they did not know of any; but I doubted them, and I doubt them still, though I did not find any. There was nothing left for us to do but to get through the forest as best we could; we had no thought of going back. Our course lay east, and the peak of Békulúsi in the distance was a good point to work to. So off we started.

It took us three days to get clear of the forest, until we came out at the villages on the left bank of the Manúnguárivu. It was a terribly difficult and rough piece of travelling, more especially so because our way took us over a mass of hills, all up and down, not a piece of level country anywhere. In some parts we found the ground covered with a kind of rattan-cane, which was most difficult to get over. We crossed several considerable streams as we went along, all trending along to the Manúnguárivu. The scenery is grand in some of the valleys-lofty rocky precipices, a dense forest on either side, the banks of the stream lined with graceful palms and strange ferns, the stream rushing and tumbling over the rocks, making a thousand cascades and bright little waterfalls. After three days we cut our way out of the forest, and after passing through a number of villages and gardens, arrived at the town of an old Betsimisaraka friend, and there camped.

At the back of this town rises the lofty hill of Békulúsi, one of the highest in North Madagascar. According to native report, no European had ascended it till I did so. I took with me three men, and thought I should be able to reach the top by evening; but the way was too rough and the forest too thick for that, and we did not arrive at the summit till late the next morning. The whole mountain is thickly wooded; as we go up the large trees gradually disappear, and palms, pandanus, and new varieties of ferns are seen. On and about the top, the ground and all the bushy vegetation is covered with a light kind of moss; in some places it is quite 18 inches deep. Here there are no large trees, only a few scraggy bushes and heath-like plants.

After finishing my observations we descended again, and reached the camp about noon of the third day. Some few weeks were spent 
making various collections, and then we went over the mountains to Ankarámi, and on to Anórontsánga by way of Bézávuna.

I remained some few days in Anórontsánga, and then hired a boat to take me slowly down the coast, my object being to collect as I went along, and then, making Mujangá my head-quarters for a time, to continue my operations in the surrounding country.

After bidding farewell to our friends at Anórontsánga, we went on board, and, taking a south-west course, a good stiff breeze soon brought us under Nósi Úvi, and after passing between Nósi Fáli and Nósi Mbalíha, we took a more southerly course, and touched the coast at Andránumbélu, where there are a number of Sakalava villages. We went ashore, and after a little nexotiating were given a house to make use of. Throughout the night there was a great deal of noise-shouting, singing, and dancing. The sister of a Sakalava queen living in an adjoining village was very ill, and a semi-religious ceremony with incantations was being performed for her benefit, in hopes of her recovery. The next morning, after giving a present to the chief man of the village, we resumed our journey down the coast. Early in the day we passed Nósi Sába, and afterwards the villages of Kírakángi and Lúza. Towards evening we had passed Nósi Láva, and arrived safely at Andrúnjina.

This being a Hova settlement, I sent a messenger to report our arrival to the officer in charge, who at once invited us up to the Ruva. After delivering the passes I had from Rakotovau, and the usual preliminaries, the officer made his professions of welcome, gave us a house to use, and shortly afterwards sent on the usual queen's present of food. We stayed here all the next day to look about the country. The Hova officers, too, were glad to have us, for the place is quite off the high-road, and seldom visited by strangers. The district is a dry and barren onechiefly a reddish loam, elevated some 50 feet or so above the sea.

The next morning we were up early, bid good-bye to our Hova friends, who had been very kind to us in a quiet manner, and set sail across the mouth of Naréndri Bay. A strong wind was blowing, and in two hours we had reached Cape Meromóni, a distance of some 15 miles. Having passed the Point, we proceeded slowly down the coast. Here a soft sandy beach stretches away for several miles, and a belt of fine. casuarinas extends all the way just above the high-water line. At night we drew the boat inshore, and camped in a little grove of trees close by. The greater part of the long cape which forms the west side of Naréndri Bay seems to be quite uninhabited. We had not seen a native since we left Andrúnjina. The country is all very dry, sandy, and covered with a bushy vegetation.

As soon as our boat was afloat the next morning we started down the coast again, and in about two hours we reached a great mass of limestone rocks, composed almost entirely of fossils. These extend along the coast for a considerable distance, and the south end forms Cape Mazámba. 
The most wonderful feature connected with these rocks, is the manner in which they have been cut up into passages and gullies, by the action of the water. I and two of my men went ashore here to look at the rocks, and then we cut across the country to some Sakalava villages, situated at the head of the Bay of Mazámbu. We waited for the boat to come up, and intended to go on; but, the water being low, we could not get away. We therefore applied to the Sakalava chief, who gave us a house, and we stayed for the night. There are some large tracts of swampy ground at the head of the bay, covered with belts of the rafia palm. This palm is largely used by the natives in the building of their houses, and many constantly employ themselves in peeling the skin from the young green leaves, which they dry, roll up in bundles, and sell to the coast traders. This forms the rafia grass so much used by gardeners.

We started out of the bay the next morning about seven o'clock, and proceeded down the coast towards Mahajámba Bay. In about two hours we arrived at a little rocky bay where a European ship had gone ashore, and was afterwards broken up by the Sakalavas. Some few pieces of her timbers still remained on the beach. Moving slowly along the beach, we came to Ambúngumbé, a kind of makeshift village just under a high cliff. The people were a mixture of Sakalavas and Makuas, who had come from their villages inland to do some fishing. We stayed with them three days; they were very quiet, pleasant people, and gave us guides to take us wherever we wanted to go. The country is an elevated plateau of red sandstone, ending abruptly in a perpendicular cliff near the beach. The plateau is covered with a thin forest, but there are no large trees. The ground is very dry, and apparently very unfertile.

Leaving Ambúngumbé, I intended to go to some of the villages at the head of Mahajámba Bay, and stay for a while; but when we were near the entrance, the "varatraza," or land-breeze, was blowing so strong that we could not enter, so we had to pass on and make the best of our way towards Mujangá. It was as well, perhaps. I was not able to visit these villages, for shortly afterwards they were attacked by "marafela," or robbers, the places looted, several natives killed, and amongst them a French trader. In the evening we anchored off Márasakúa, and the next day, after a long run down the coast, we rounded Cape Ampásimárini, arriving at Mujangá about three o'clock in the afternoon. Here I received a hearty welcome from Mr. Stratton C. Knott, British Vice-Consul at Mujangá, and by his kind help I quickly obtained a house and settled down comfortably for my work.

By Mr. Knott's assistance, I soon got through the usual formalities incident upon a traveller's arrival at a Hova centre. $\mathrm{He}$ kindly introduced me to the governor-general, obtained for me the necessary papers and passes required by one travelling about in the district, and

No. III.—SEPTEMBER, 1895.] 
afterwards we went together to a grand dinner given by the governorgeneral to celebrate the departure of his son for France. Mujangá stands in great contrast to all the Malagasy towns on the west coast. It is the only one that has good stone-built houses, and these give the place quite a substantial-looking appearance. They are all built as near as possible to the beach, and belong chiefly to the Hindi traders. The native houses are built chiefly of palm-leaves, sticks, and rushes. The Hova part of the town is built on some rising ground about balf a mile inland; and a short distance away there is an old dilapidated fort. Groves of mango trees, guavas, and mabibu cover the adjacent country, and give a most pleasant shade.

After a few days' stay in Mujangá, I left for a trip inland to Bétsáku, a Hova station some fifteen miles distant. The first stage brought us to Anpárangídu. Here we rested for the night, and the next day, after a march of about ten miles, we reached Bétsáku. The whole of the country is very undulating. There are numerous lakes, which abound with crocodiles and fish; they are also the home of a great variety of ducks and other water-loving birds. Bétsáku is situated on rather rising ground. It is not a large place now, but the surrounding country seems to indicate that when it was held by the free Sakalavas it must have been a very populous district. Here the lakes are much larger than those we passed on the road; they are all surrounded by belts of rafia palm; and crocodiles, fish, and water-birds are present in great numbers.

I went through the usual formalities with the governor in charge as soon as I arrived. He received me very graciously, and placed one of his houses at my disposal. The usual queen's present of food was duly sent in, and this was followed by a friendly interchange of visits between the governor and myself.

I remained collecting in the country for about three weeks, and then returned to Mujangá. The day before leaving Bétsáku, the governor gave me a farewell dinner. After dinner he called up all the women and girls of the place before the front of the house, where they went through a series of song-singing; they were then drilled in groups like soldiers ; and after this they performed four or five charades, accompanied by singing and acting. This over, I had to give a present to the governor for them, and they retired.

On reaching Mujangá I shipped my collections home by the mail, and then hired a boat to take me to Antsúha, a place some 30 miles west-southwest of Mujangá. To reach this, we had to go outside Bémbatóka Bay and down the coast past Nósi Makúmba. Towards evening we anchored just inside one of the many inlets hereabout, and next morning proceeded up the river with the tide. We had hoped to reach our destination during the day, but, the water failing us, we did not reach it till noon of the next day. A new village had recently been built on a point of 
land nearly surrounded by water. The old place had been deserted because some one had lately died there, it being on that account considered bad. The natives here are of the worst kind of Sakalavas. They have never been conquered by the Horas, and for many generations Mohammedan immigrants from the Comoro islands and Zanzibar have had considerable influence amongst them-so much so, that all their chiefs and many of their people make a kind of profession of Mohammedanism ; and they are amongst the leaders of the West Madagascar slave trade. This trade is, or was, very extensively carried on at every place of importance on the coast between Mujangá and Mórondáva; most, perhaps all, of the slaves passing through the hands of these Mohammedan traders from the Comoro islands and Zanzibar. They fetched cargoes of Makuas from East Africa to sell to the Sakalavas, and the Sakalavas selling to the Mohammedans all such other Malagasy people they had taken by war or in any other way.

On account of the slave trade, the Sakalavas along this piece of coast have the greatest objection to Europeans visiting their country, for their Mohammedan friends have not failed to inform them with what aversion white men, generally, look upon the traffic, and of the means which are used to suppress it. This has made the strip of country between Mujangá and Mórondáva almost, if not quite, the most difficult to enter of any in Madagascar, and to this day the whole of the country lying inland from this part of the coast is little or no better known to Europeans than the Máhafáli or Antandrói countries in the south of Madagascar. The chief of Antsúha seemed somewhat friendly when I arrived, and gave me a house to use, but when he found he could not get from me everything he asked for, he began to make himself disagreeable, and put obstacles in the way of my men collecting the things I wanted. I only stayed about a week in the district, and then returned to Mujangá.

My next short journey was to Katsépi, a Sakalava town and district lying on the west side of Bémbatóka Bay, and opposite Mujangá. We went by boat, and arrived in the evening. On landing, a messenger was sent to the queen, who ordered a house to be given us. This was done, and the queen sent word that she would see us on the following day. The next morning I sent my men off collecting, and in the course of the day the queen came. I had to tell her my business, though she had already learnt it; afterwards I gave her a considerable present, and she granted her permission for me to collect whatever I wanted. I spent about a fortnight hunting all over the country. I did not get much in insects, but secured some fine specimens of lemurs.

The country is of mixed formation-that near the coast very undulating, covered here and there with belts and large patches of forest, other parts open and clothed with a coarse grass. Some of the highest spots are crowned with huge Sakalava graves. These are from 50 to 60 
feet long, 15 feet wide, and 5 or 6 feet high. They are enlarged from time to time by fresh bodies being buried at the ends, and further accumulations of stones added. The part of the country near Bémbatóka Bay is flat, and composed of a hard kind of limestone. In it there are numerous deep holes and cavities; everywhere the softer parts of the rock have been washed away, leaving only hard rocky points, which are most difficult to walk on. The whole of this part of the country is covered with a thick forest, the home of several species of lemurs, the wild boar, and guinea-fowl. Having finished my collecting bere, I returned to Mujangá, where I packed up my collections, and Mr. Knott kindly undertook to ship them home for me.

When I left Mujangá by the French mail, my intention was to land at Máintiránu and collect there for a time, but on the steamer's arrival off that place, there was such a high sea running that it was impossible to land, and I had to go on to Mórondáva. On arrival at Mórondáva I received a most hearty welcome from Mr. W. Donavan, one of the chief traders of the place, who kindly gave me the use of one of the houses in his compound, and assisted me in every way possible.

The place commonly called Mórondáva is really a sandbank named Nósi-miándraki. The village of Mórondáva is situated some two or three miles more south, and was formerly a rather important place, but now Nósi-miándraki takes the lead. It is here the mail-steamer calls, and all the traders have their houses of business. The country round about is a large flat delta formed by the river Mórondáva, which here enters the sea through a number of creeks and streams which cut the delta into several small islands. These are mostly covered with a dense mangrove vegetation, and the whole district is very unhealthy.

After a few days' stay about Mórondáva, I started off to Mahábu, a district some two days inland. I could have gone by water, but I prefer the road to the milanga, a shallow, round-bottomed canoe. The path took us through a long stretch of mangrove swamps, and then we crossed a large marshy plain. Here there is a considerable settlement of free Makuas. It is a pleasure to contrast their clean, tidy homesteads with the dirty hovels and surrounding of the Malagasy. The Hovas especially are the dirtiest in their houses and town of all the Malagasy I have seen. I had met some of these Makuas at the coast, and on arriving at their village they gave me a hearty welcome. They were delighted at my being able to converse with them in Swahili, and more especially when they learnt that I had travelled all about their fatherland, the Makua country, in East Africa. Anything they had I was welcome to. Most of these people are professedly Mohammedans, but some few attend the Norwegian Lutheran Mission Church close by. Passing on from the Makua settlement, we entered a thick forest of rather bushy trees. We traversed this for some distance, and then arrived at a large open space occupied by a Sakalava village. The 
natives here keep a good number of cattle, so I wanted to buy some milk. On offering some silver in payment, they refused to take it; it was "fadi," a forbidden thing, for them to use silver. They absolutely refused the silver, but gladly took two or three empty bottles in exchange.

The next part of the journey was through a forest growing in an immense swamp. This is always somewbat muddy, and especially so at spring tides, at which time it becomes covered with salt water. We now arrived at a piece of country which had formerly been covered with a dense forest, but now only belts and patches of it remain; the rest had been cleared away by the natives to make new gardens. The principal feature in the vegetation is some fine Adansonias (baobabs). These are about 10 feet in diameter at the base, and rise up 80 or 100 feet straight, and then send out a small branching top. Sometimes the common baobab, very stout and somewhat short, with large gouty branches, is seen, but the former predominates. Just on the outskirt of the forest we came to a group of villages situated on the left bank of the upper outlet of the Mórondáva river. Crossing to the right bank, we entered upon a large tract of flat bushy country. A little to the left of the path as we went along we saw a number of villages partly hidden by the bush. A few Hovas are settled here, whose duty it is to collect the "isan-pulu" or tax on the produce of the district. The inhabitants are chiefly Sakalavas, with a few Makuas. Proceeding on for about two hours, we came to a wide valley, having a piece of somewhat rising ground stretching along the hollow. On this a large Sakalava village has been built, and there we took up our abode for the night. We had some difficulty in getting a house at first, and even when we had arranged for one we were not allowed to enter it till we had paid the price demanded. This was a rather strange action on the part of a native; but I suppose some Creole trader or other had lodged here previously, and had gone off without paying his bill, and this time the owner intended to make sure of his money.

We started early the next morning, and after four hours' marching arrived at the village of Bésakúa, and made a halt for breakfast. Whilst this was being prepared I went out and shot some sand-grouse, and on returning found it was "fadi" for the natives to either shoot them or bring them into the village; they did not object to my shooting the birds, but requested me not to bring them into the village. These birds, so the natives said, were made "fadi" because they had saved the village from destruction some time ago. A covey of these birds, being disturbed by an advancing enemy, rose up, with their usual loud cackling which they make whilst flying; the natives, alarmed by this, discovered their enemies approaching, attacked them, and drove them away. Thus the birds saved them from a surprise, and their village, probably, from destruction. 'Two hours' further travelling, and we 
reached the important Hova settlement of Mahábu. This is well enclosed by a thick reketa (Opontia) hedge, which quite hides the buildings of the town from sight. We halted just outside the principal gate, and sent a messenger to announce our arrival to the governor. The men returning, we were told to proceed at once to the Ruva, where we received a warm welcome from the governor Razafindrazaka. I had previously met the governor at the coast, so had no formalities to go through with him. He at once placed a fine house at my service, and offered to do all in his power to assist me in my work. To celebrate my arrival the governor gave a great dinner, to which all the chief officers of the district were invited, and to help me on in my work he placed at my disposal a number of Ampelakalefu, or Taimero men; these are a brave, hardy race of men, who go in parties all over Madagascar in search of work. They suited me well, for they are not afraid to go about the woods as most natives are.

Mahábu town is divided into two parts, but all is enclosed by one huge raketa fence. The Ruva, dwellings of the principal officers, church, and school are fenced off on one side of the enclosure. The other part is occupied by the ordinary Hova inhabitants, and contain nearly two hundred houses. On the Christmas Eve of 1890, I saw the whole of the houses in this part of the town burnt down in about two hours. A Hova, contrary to law, was distilling some rum for the coming festivities; by some means his house caught fire, and the native building-material being of such an inflammable nature, all efforts to put it down were unavailing, and it burnt itself out. The official part of the town was saved by the huge raketa fence which intervened.

Outside Mahábu town the country is all very flat and somewhat low. It is chiefly covered with a thick forest, with an occasional open space. To the north there is a large lake abounding with crocodiles, and a considerable number of ducks and other water-loving birds. There are no towns in the neighbourhood to the north, but at a short distance to the south the river Mórondáva flows past, and this is well populated on both banks. The people are a mixture of Sakalavas and Makuas, who are generally well disposed towards strangers, but they all have no love for the Hovas. I frequently camped about amongst these villages, and the natives always treated me with kindness and respect.

After a few weeks' collecting in the neighbourhood of Mahábu, I started with a party of men to visit the Máshakúru districts lying to the east of the Tsíandávana hills. Shortly after leaving the town, we crossed to the left bank of the Mórondáva, thence on for a few miles through Sakalava gardens and villages, and we crossed to the right bank again. The river is fordable in many places during the dry season, but when full, during the rains, it is very deep, and the rush is so strong that it is most dangerous to attempt to cross, even in a canoe. Passing 
along, we came to the ancient burial-place of the Sakalava kings and chiefs. The greatest reverence was shown in passing these tombs, and all, even the Hovas, took off their hats as a mark of respect. The graves are the usual large square piles of stones, only those of the royal family are much larger and better built. At Mórondáva the coast Sakalavas do not bury their dead under heaps of stones, but in the sand, and then build a palisade round the grave with posts, rails, and palings. The top rail is carved with figures of oxen, canoes, crocodiles, and other figures; the posts are generally ornamented with figures of men, women, birds, and water-pots. The road now took us over some rough undulating country, watered by several small streams, and thinly wooded. Towards evening we reached a group of Sakalava villages, and camped for the night.

Next morning we resumed our march, and a two hours' brisk walk over a flat bushy country brought us to the little river Tsesí, flowing at the foot of the Tsíandávana hills. After a short rest we had a stiff climb to reach the top of the hill, where there is a wide plateau. This is covered with a short grass, and is almost devoid of trees. The largest tree we saw was a tamarind standing on the edge of a small pond. Close by here the road branches off, one part going north-east to Málimbándi, the other east to Bérunúnu. We followed the latter, and soon saw a change in the appearance of the rocks; they gave one the idea that there had been an immense fire, and all the stones had been melted up into masses of blacksmith's hards, or slag. Now we began to descend, and, following a tortuous path about the hillsides, arrived at a fair-sized stream flowing in a deep gully. Two miles down this stream brought us near to the Bérunúnu villages. We halted and sent messengers to inform the chief of our arrival. After waiting some time, the men returned with orders for us to proceed to the village. Here we were met by the chief and his people, to whom we explained the reason of our presence among them. When the usual formalities were ended, the chief gave me two good houses for my use, and then sent in a big present of food-a goose, fowls, ducks, rice, and eggs, and a promise of as much milk night and morning as I liked to use. We were soon comfortably settled, and then I visited the chief in his own house, and, after explaining to him more fully what I wanted to do, thanked him for the very friendly reception he had given us; and he then informed me that the country was open for me to go where I pleased, and that he would give me men whenever I wanted them to guide me about. This was exceedingly kind of the old chief, and the best of it was he kept his promise to me.

I remained some two months in this district, and here shot my first fusa (Cryptoprota ferox). He was curled up on a big branch of a tall tree. I thought it was a large kind of lemur; a charge of buckshot brought it down, and I was agreeably surprised to find it was the animal 
I had been so long looking for. I had seen one previously at the foot of Békulúsi hill, but, being without a gun, was unable to get it.

I remained in the neighbourhood of the villages for the first few days, and then went and camped about the forest, the old chief every now and then sending me fowls, rice, and other food from the village. He also gave me two oxen to be killed for the men who were with me. These did not cost him anything, for he was really the chief of a band of marafela, or cattle-stealers. Whilst I was there the men brought in three large herds which they had stolen from some villages at a distance. The hillsides are covered with a thick forest, and are alive with lemurs, fusas, wild boar, and many other animals. The valleys are low and swampy. There are many good-sized lakes, which abound with ducks, geese, and other wild-fowl. Across the large valley a piece of slightly rising ground forms a kind of watershed; the water on the south drains into the Mórondáva river, that on the north enters the Tsiandúa-a considerable stream which flows into the Tsíribihína-and thence into the sea at Tsimánandrafúzana.

When I had finished my work of collecting, I returned to the coast by way of Mahábu, taking two men with me from the old chief who had been so kind to me. These I sent back again with presents to the chief, that he might see that I had not forgotten him nor the kind manner in which he had received me.

Soon after my return to Mórondáva from my expedition to the Máshakúru at Bérunúnu, the little French steamer Mpangaka arrived, on her way to Nósi-vé. My collection inland had been packed up and handed over to Mr. Donavan, to be shipped home by the next mail. The men who had accompanied me thus far, being frightened by the wonderful stories they had heard of the Sakalavas and Mahafalis in the south, declined to go any further, so I had to discharge them; only one man, a Hova, Rabe by name, ventured to go on. With him I embarked on board the steamer, and, after a fair run of twenty-four hours, arrived at Nósi-vé. This is a small sandbank, nearly a mile long and about a quarter of a mile at its greatest width, surrounded by an extensive coral reef. It is situated about 3 miles off the Mahafali coast, in about lat. $23^{\circ} 40^{\prime} \mathrm{S}$. It was uninhabited some forty years ago, but at that time the Sakalavas and Mahafalis became so extortionate and troublesome to the traders, that they all retired to this island, and made it their head-quarters. Now it is nearly covered with traders' houses and stores, and has become the principal trading-place on the southwest coast. The traders are English, French, French Creoles from Mauritius and Bourbon, and Hindis from Zanzibar and Bombay. The native population is made up of a mixture of Sakalavas, Mahafalis, Hovas, Antinosi, some few Makuas and Betsimisarakas. The French have established a Vice-Presidency here.

On arrival at Nósi-vé I went at once to Mr. Oman, a well-known 
merchant, and was received by him in the most hospitable manner. I stayed in Nósi-vé for about a month, and then went over to Salári, a small Mahafali village on the lowland, near the mouth of the Ong'ulahi river. Here Messrs. Proctor Brothers, of London, have a station, and Mr. Hooper, their agent, kindly invited me to take up my quarters with him. My chief object in coming to this part of south Madagascar was to penetrate, if possible, into the Mahafali country, and for this purpose I remained for several months about Salári and its neighbourhood. I made several attempts to get inland, but was always baffled by the natives, who have the greatest objection to Europeans entering their country. Finding my efforts in this direction were so far unsuccessful, I resolved to go away for a time and explore and collect along the coast north of St. Augustine's Bay. For this work I bought a good-sized lakam-piara (outrigger canoe), and hired a sailing-boat of about three tons, and with these visited and collected in all the chief places between Lámbubára, lat. $22^{\circ} \mathrm{S}$., to St. Augustine's Bay.

The most northern part I explored in this manner was Murder Bay. This is an extensive inlet, bounded by wide mangrove swamps. On the north side of the bay the swamp is cut up into a number of islands by creeks which traverse it in all directions. There are several Sakalava villages on the north side of the bay, and on the bank of one of the creeks the trading station of Lámbuhára is built. The traders are chiefly Creoles and Hindis. The Hovas have no authority in this part of the country, nor any, in fact, in all the districts lying between lat. $21^{\circ} 30^{\prime} \mathrm{S}$., a little south of Mérondáva, and Tuliá in St. Augustine's Bay. The whole country is purely Sakalava, and ruled by Sakalava kings. These are somewhat despotic in their manner, as their actions sometimes show.

On the south side of Murder Bay, three or four groups of houses form the village of Itampúlu-bé. It is built close to the coast, on a flat limestone formation. All the country round about is of the same formation. In it there are some basin-like depressions, now silted up. The upper stratum is a soft black soil, and underneath there is a thick layer of white or greyish loam, full of fossils. Here I procured some of my finest specimens-remains of apyornis, hippopotamus, bos, potamachærus, crocodile, and varjous other mammals and birds.

The country inland is a vast flat, very fertile, extending inland to the range of hills, which stretch in an almost straight line from this place to St. Augustine's Bay. There are a number of lakes about the flat, one very large not far from the king's town. There are but few natives living on the coast in this part of the country, most of the Sakalavas here being Máshakúru. The southern Sakalavas are divided into two sections rather than tribes. Those on the coast are chiefly Vezu, whose principal employment is fishing and boat-sailing, though they do some amount of gardening, and keep good herds of cattle. The other section are called Máshakúru. They are essentially herdsmen 
and agriculturists. The Vezu despise the Máshakúru because they are countrymen or bushmen; the fiercer Máshakúru look with contempt upon the Vezu because, though noisy, they are cowards.

Nearly all communications between places on the coast are performed by boat or canoe. A reef extends along the coast at a distance varying from half a mile to three miles, and this, breaking the heavy seas, make it perfectly easy and safe travelling. There are several openings in the reef, by which larger vessels can enter either for safety, or to bring up at the villages along the coast.

Leaving Murder Bay, we rounded Isípuki point, passed Vúhits-ábu or Talá, down past Famátaléfu or Mándi, thence to Ambátumilú and on to Mámiránu. Most of these places were inhabited formerly, but now it is quite deserted. The coast-line is generally a succession of sandhills, but here and there sandstone rocks crop out, and these are frequently covered with a limestone, coral formation, or perhaps it is a kind of fossilized wood. I brought some specimens of this rock home for examination.

Leaving Mámiránu, we passed Ándravúnji and Salári. Near this place there is a large opening in the reef, named Kazu-bé-vuhitsi, through which a ship of a hundred tons or more can enter. Thence we went on to Ambátumifúku (the place where the water makes a noise in the holes of the rocks). A most interesting line of sandstone rocks extends along the coast. In making an examination, I found they contained quite a number of land-shells very similar to species still found alive in the locality; but what surprised me more was to find pieces of the broken eggshell of the æpyornis embedded in the rock. This circumstance alone is proof of the vast antiquity of the bird. The tops of these rocks are covered with either a coral formation, or what I think may be fossilized wood.

This line of rocks, besides stretching along the coast for some distance, extends inland for two miles or more, and on the side facing inland there are extensive waterworn caverns, in which I was fortunate enough to discover, at different times, several fossil carapaces of gigantic tortoise (Testudo grandidiere). Two of these are now in the Geological Gallery of the British Museum, South Kensington, and one or more in the museum of the Honourable W. Rothschild, at Tring. From the reports given me, I believe there are many other caves and places in the neighbourhood still worthy of being examined.

From Ambátumifúku we proceeded south, and passed quite a number of places previously occupied by villages, but now deserted-Tampúlu, 'T'síandámba, Isaléka, Isífuta, Ampásiláva, Ankílimihúaki, and Fihiérng'amasai. This latter place, as we went up, was inhabited, and apparently in perfect safety; when we returned we found it quite deserted-the people had been frightened away by reports of Rungavuli. Thence we went on to Melíkuki, a dangerous rocky point stretching out some 
distance into the sea. On this point, the "lulu," or huge stone graves of some of the chief families of Manúmbu, are built. A short distance further on and we came to Manúmbu. This is the largest Sakalava town on the west coast of Madagascar, and contains, probably, between three and four thousand inhabitants. It is divided into two parts by the river Máhanúmbu. Manúmbu proper is built along the seacoast on the right bank of the river; the other part, Fitsitiki, along the coast-line on the left bank. It is inhabited chiefly by Sakalavas, and a few Makuas; to these must be added a few European, Creole, and Hindi traders. The king of the place, and all the surrounding country as far as the river Ong'uláhi, is Tumpumana-now a fairly quiet man, but formerly a terror to all traders and strangers in the country.

I had occasion to visit the king some three or four times. All foreign strangers when visiting the king are supposed to shake hands with him, instead of grovelling before him as the natives do; but he makes them pay for this concession by demanding that every white man shaking hands with him for the first time shall at the same time leave a piece of gold in his hands. The various towns and villages are ruled by the local "masondranu," or chiefs. Those of Manúmbu are Tsialala, Saruveta, and Mahiti. They try all the cases which arise between natives, or natives and strangers; but they are not allowed to do it all their own way. All the freemen of the place have a word in the matter, and if it cannot be settled satisfactorily, then an appeal is made to the king.

From Manúmbu we went on to Ambúlisátra, passing on our way Úrantámbu, Kúafasi, Andrévuki, Fanandúmutsi, Itúnga-bé, and Béfutúa. The only inhabited place is Andrévuki, a small but rising town. There is not a town really at Ambúlisátra, only a few little huts occupied by some herdsmen who here attend to the king's cattle. There are several herds, some belonging to kings, or rather named after kings of generations back. All these are kept separate from the present king's cattle, and supply the necessary victims for the royal sacrifices.

The district of Ambúlisátra is important, for here has been discovered some of the most remarkable fossils of Madagascar. M. Grandidier, several years ago, made some of his finest discoveries here. I made several visits to the place, and was equally fortunate, especially in finding the head of the Megaladapis Madagascariensis, a gigantic fossil form of lemuroid. This has been described in Philosophical Transactions of the Royal Society by Dr. C. J. Forsyth Major. This is a remarkable piece of flat country, and has, undoubtedly, at some remote date, been occupied by an extensive lake, of which only pond-like depressions remain. I believe there are neither fish nor crocodiles in these small lakes, but I have frequently seen some hundreds of the scarlet flamingo (Phonicopterus erythreus) congregated there.

Passing on from Ambúlisátra, we sailed for several miles along a 
piece of coast well wooded and somewhat rocky. At one time it had its towns and people, but now only the names remain. These are Antévaména, Máraházu, Fáti, Berávi, Lúhatáng'a. A considerable lake inland is named Ránu-bé (Big-water), and a village near by takes the same name.

From Lúhatáng'a a long stretch of sandbanks extend to Fihireng'a, or Tuliá. On these banks there are a number of small villagesBelítsaki, Bélalánda, Ambúliránu, Ambaráta, and others-inhabited chiefly by Vezu-Sakalavas, who are somewhat under the control of the Hovas at Tuliá, but ever ready to take to their canoes and decamp should they feel the Hova authority bearing too heavily upon them. Fihireng'a-or Tuliá, as it is often called-is the chief Hova station in South-West Madagascar, the head-quarters of the few little stations round about. From this place to near Fort Dauphin, on the south-east coast, the country is entirely in the hands of the natives, nor would the Hovas dare to go into the country. Even here about Tuliá the Hovas have no established authority over the natives, who look up to Tumpumana as their only king and ruler. The principal business of the Hovas is, apparently, to collect the isan-pulu or custom duties, and they do not seem to do anything else. Certainly they do nothing for the Sakalava natives, for they neither restrain them in their tribal wars and disputes, and protect them from the raids of robbers, who carry off both their cattle and people, nor have they established any schools or used other means to elevate them in any way.

The town of Tuliá is built on a long sandbank running parallel to the beach, and is a somewhat important trading centre still. But previous to the arrival of the Hovas it was the chief town on the coast; now Manúmbu takes the lead in numbers. At the back of Tuliá there is a large tract of flat country, very fertile, formerly cultivated by the Sakalavas, but now abandoned.

So much has been written concerning the Hovas, and so little about the other tribes, that there is a general impression that the Hovas have established themselves all over the island. This, however, is quite a mistake; probably not half the natives of Madagascar recognize the Hovas as their rulers and Ranavalona as their queen. A straight line might be drawn from Mujangá on the west coast to Fort Dauphin on the south-east; there are but few real subjects of Queen Ranavalona west and south of that line. Most of the minor tribes in the south-east are as free as ever they were, and much the same may be said of the Antankaranas in the north.

The burial-place of the southern Sakalava kings is situated a few miles inland from Tuliá. This is enclosed and constantly guarded by a certain family of Sakalavas. No one is allowed to enter except at royal funerals or on certain appointed occasions. In a piece of water not far from this place there are a number of crocodiles which are 
considered sacred, and no one is allowed to kill any of them. They are preserved for the sake of their teeth. When a king dies, a crocodile is caught alive, one of its large teeth extracted, and then it is set free again. The hollow tooth of the crocodile is required as a receptacle for "gini" of the late king; that is, a tooth, finger-nails, and other parts which are held to be sacred, and must therefore be preserved.

After returning to Nósi-vé from Ampaláza, I went on several short collecting trips to Manúmbu, Tuliá, and other places on the Sakalava coast.

When I arrived again in Nósi-vé after these trips, I learnt from Mr. Oman that Befanatriki, an Antinosi king from the interior, was coming: to the coast. Mr. Oman, as well as myself, wanted to go inland, and thinking that probably the king would allow us to go up with him when he returned, as soon as we heard of his arrival at Anatsúng'u, a town at the mouth of the Ong'ulahi river, we went over to see him. He received us very kindly, and not only readily fell in with our wishes, but also agreed to supply us with all the porters we needed for our baggage.

On the third day the king gave the order to start. We were a party of about eighty, all told; the king remained behind with his wife and a few men, saying he would come on shortly. Our path took us through the gardens on the strip of low ground on the right bank of the Ong'ulahi. The first day's journey was a long and tiring one, partly over sand, sometimes in the river, and in other places carefully picking our way along the steep and rocky spurs of the hill, which here slopes down into the deep channel of the river.

We passed several villages as we went along, the most important being Ifenuarívu, the residence of Ramara, an influential Sakalava chief.

Towards evening we entered the district of Ilánza, held by an independent Sakalava chief named Tsilivani. Next evening Befanatriki came up with his household and the rest of the men, and the next morning we resumed our march. This took us by a tortuous path up the hillside till we reached the plateau above. Here the path took a north-north-east direction. At night we encamped in the thick forest near the path. The Malagasy never like to camp in the open, nor yet keep up fires at night. The whole of this district is an elevated sandstone mass, overlaid with a stratum of limestone full of shells. The country is covered with a thick forest, with here and there open glades clothed with a coarse grass.

The next morning we resumed our journey, and passed over a more undulating country, and finally came out on a broad open plain. This is but lightly wooded, excepting a few belts of forest here and there. A number of lakes are dotted about the plain, but during the dry season they become nearly dried up. About the middle of the afternoon we had crossed the plain, and arrived at the edge of the plateau, from which we could look down into the valley which extends to the Ong'ulahi, some 10 miles away. 
After a few days' further march we reached the large village of Ilúnti, and crossed to the left bank of the Amantaki. We then went on in an easterly direction over some undulating ground till we reached the Isakamaré, and crossed over to the left bank; thence our course was almost due north. We had now reached the northern end of the Bekuráki range. Going on, we found the hills on the right bank of the Isakamaré, a continuous unbroken range. Those on the left bank form a group most extraordinary in conformation and appearance. They rise to a height of about 1500 feet; the sides, which are very precipitous, and in some places quite perpendicular, enclose narrow valleys, coursed by small rivulets which flow into the Isakamaré. The scenery is of the most varied composition. In one place the towering rocky masses induce a feeling of awe and grandeur; a little further on, another reach of the smooth-flowing river, with its banks graced with beautiful hanging ferns and stately palms, presents a scene of quiet and repose. After advancing up the river between the hills for some 4 miles or more, we came to the village of Ambatulúaki (at the hole in the rock), and rested. This is the most northern part of King Befanatriki's country.

After a brief stay we commenced our return journey down the Isakamaré. The most remarkable feature about the whole country we had traversed was a number of bogs or old lake beds we came across; not only were they common all over the open country, but even in the little valleys between the mountains on the Isakamare we found them. It seems as if the lakes are a very old formation; that the sandstone hills, which are really only part of a large plateau which covered all the country about, are of later date. This plateau has now been washed away in many places, and the old lakes are brought to light again. There is no forest about the country; the nearest piece of real forest is Ambúliála, situated some 15 miles north of Manansúa. The country generally is not very fertile; but all the damp places, bogs, and marshy places are especially good, the natives every year being able to raise two crops of rice upon the same piece of land. The cultivation of rice forms the chief occupation of the Antinosi ; large quantities are raised and conveyed by "laka" to the coast, and then sold to the Sakalavas. All the chiefs and many of the people keep large herds of cattle-not that they deal much in them, but they are rather a mark of the owner's wealth and position.

Shortly after this Mr. Oman returned to the coast, but I remained at Manansúa to continue my work of collecting. This I continued for some nine months, making short trips and camping about the country in all directions. Whilst engaged in collecting insects, birds, and other natural history objects, I also engaged some men to excavate among the dry lake beds at Ilúnti and Ifúnsi, with the result that I found at both places a number of broken carapaces of a gigantic 
tortoise and of some smaller species. Amongst these fossils there were also fossilized remains of the æpyornis, hippopotamus, crocodile, and other animals.

One of the longest journeys I made during this period was done in company with Befanatriki, who went on a visit to his friend Lahmanzaka at Béfamáta, on Laki Ihúti.

I I now began to make preparations for returning to the coast, and I was very eager to perform the journey by canoe down the river. This was at last arranged in company with Befanatriki, his wife, and a considerable retinue. Our first reach down the Ong'ulahi river was in almost a south-west direction, between a lot of sandbanks. All the right bank is very low, the other side somewhat higher and bushy. The next morning brought us at an early hour to the mouth of the Isákamadíu, a considerable affluent of the Ong'ulahi. Here the country is much more hilly, rough, covered with rocks having the appearance of volcanic origin, and all is covered with a somewhat dense forest. Further inland, where the country is higher, there is no forest, but the country is clothed with a coarse grass.

Leaving Andávakakíu (at the shark's hole), the stream carried us along in a somewhat north-west direction for about 3 miles, and then we arrived at the important town of Sálu-aváratsi. Here we remained for three or four days. King Befanatriki, who is nephew of the king of this place, had some business which detained him. This place is the eastern limit of a curious geological formation, abounding with hot-water springs. The line of country occupied by these springs lies in a southwest course, and extend from Sálu-aváratsi in the east to Andránumái on the left bank of the Ong'ulahi in the west, and is some 10 miles wide. The hot spring of Sálu-aváratsi is just outside the village gates, where the water rises out of a great bed of limestone. It is used by the natives for all purposes. The steam from the rising water gives off a rather unpleasant odour, but this passes away as the water cools down.

From Ambúruki we went on to the villages of Béfamáta. Close by these villages there is a large lake, some 2 miles in diameter. It abounds with fish, crocodiles, and birds. It is said that formerly there was an extensive morass here, and the Sakalavas, living in a village on the top of Ivúhi-bé, used to have their rice-gardens all over the place. Suddenly, however, there was a depression, and the place was flooded with water from the Ong'ulahi. There are none of the inhabitants now living who remember the change taking place.

Resuming our voyage down the river, we passed the mouth of the Tahéza, the most important tributary of the Ong'ulahi, on its right bank. Further on we came to the village of Behísatri, a place geologically interesting. The village is built on a sandstone hill. The hill is, I suppose, part of the old sandstone plateau which formerly covered the whole of the country. The channel of the Ong'ulahi, sweeping 
under the foot of the hill, has washed it away so as to form perpendicular cliffs. Here one gets a fine section of the strata, which are as follows: a thin layer of blackish soil, recent vegetable débris, followed by several strata of variously coloured sandstone to within 4 feet of the water. The next stratum is a hard greenish-black mud which descends below the water's edge. This lower stratum I take to be the bed of some lake of a very old formation.

In the district of Bevítiki we reached the high plateau which occurs on both sides of the river, and which extends to the coast. The upper part or stratum of this plateau is formed of a fossiliferous limestone, then a thick mass of red sandstone resting on the stratum of a hard black stone, or rather various-shaped lumps of hard black stone, with the interstices filled up with a kind of limestone. The general height of the plateau is from 1500 to 2000 feet. It is covered everywhere with a thin forest, formed chiefly of different species of Euphorbia.

There is nothing of interest to note during the rest of the journey.

\section{THE U.S. GEOLOGICAL SURVEY.}

By MARCUS BAKER.

THE year 1894 marks an epoch in the history of the U.S. Geological Survey. Major J. W. Powell, its efficient director almost from the beginning in 1879, resigned his office in May, 1894, and was succeeded by Mr. Charles Doolittle Walcott. This event, therefore, makes 1894 a transition year; a year which may be said to close an old and begin a new chapter.

It will be remembered that the Survey was created March 3, 1879, by a consolidation and reorganization of three pre-existing surveys, known respectively as the Hayden, Wheeler, and Powell Surveys. Mr. Clarence King, the first director, resigned his office so soon after entering upon it, that the present development and organization of the survey is chiefly due to Major Powell, who directed its course and work for thirteen years, 1881-1894.

In noting the transition from the old to the new régime, a word or two respecting the two directors may not be out of place.

Major Powell is a striking personality, whose sturdy and independent thinking and acting has strongly impressed, and still impresses, all who come within reach of his voice or pen. The present Survey is in large part his creation. Under his guidance, it began on a moderate scale and grew rapidly. The confidence and support of Congress was won, and an increasing number of enthusiastic co-labourers brought into the work. The buoyancy of youth and hope pervaded the organization. Affection for the leader and confidence in him was unqualified. The annual budgets steadily increased, and all was bustling activity. In 


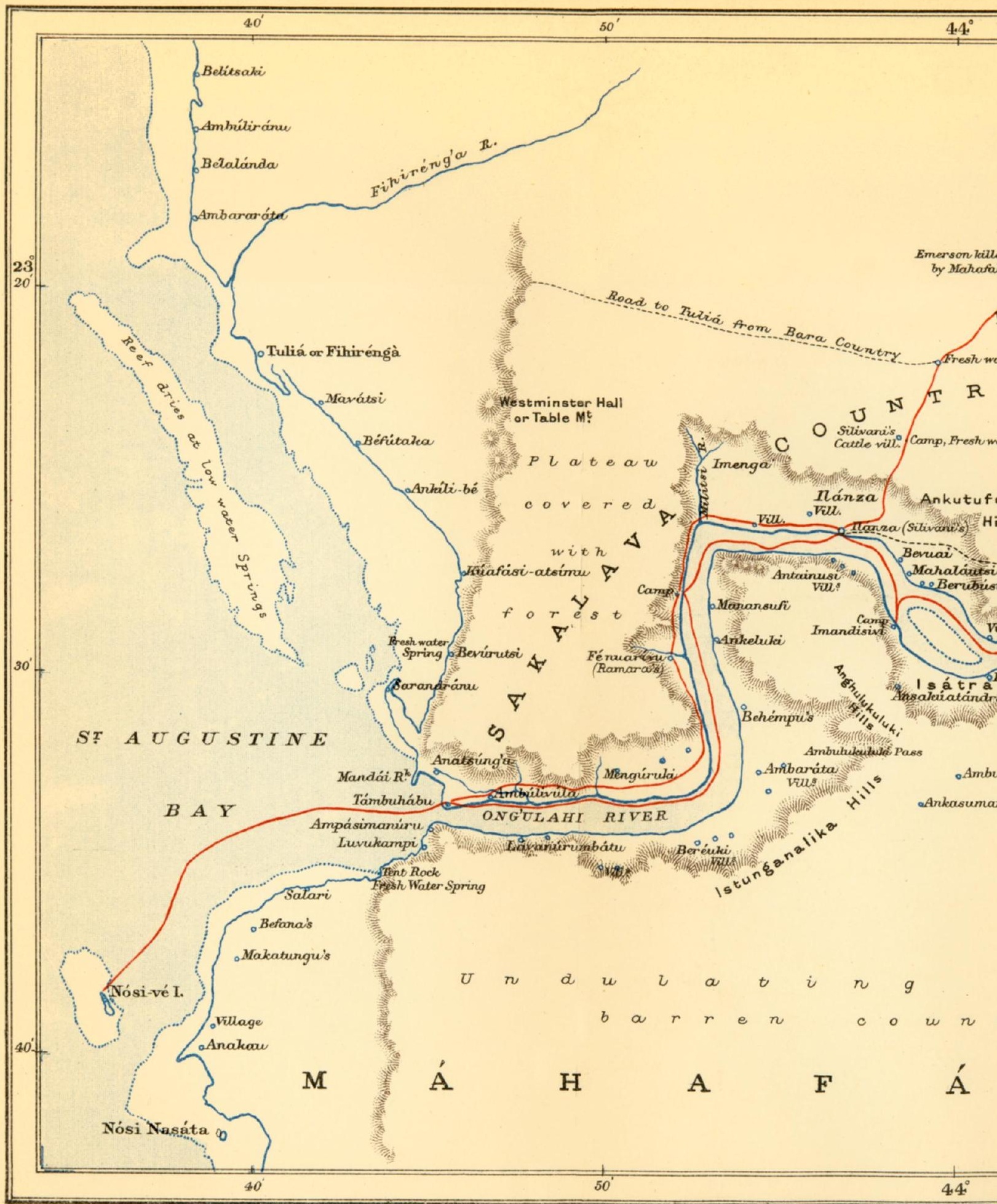

HShatbazu RGS del. 


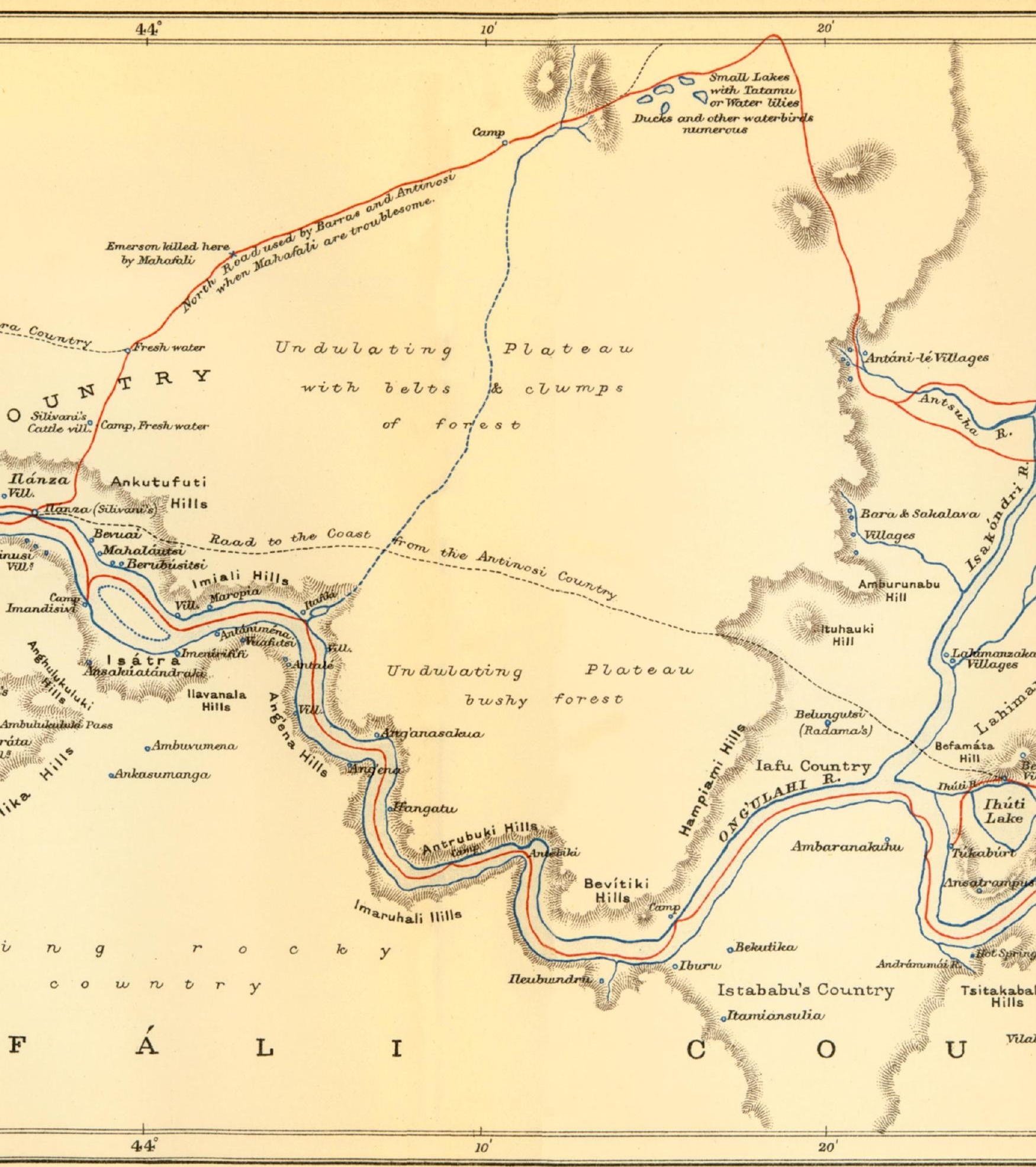

Published by the Royal Geograph 


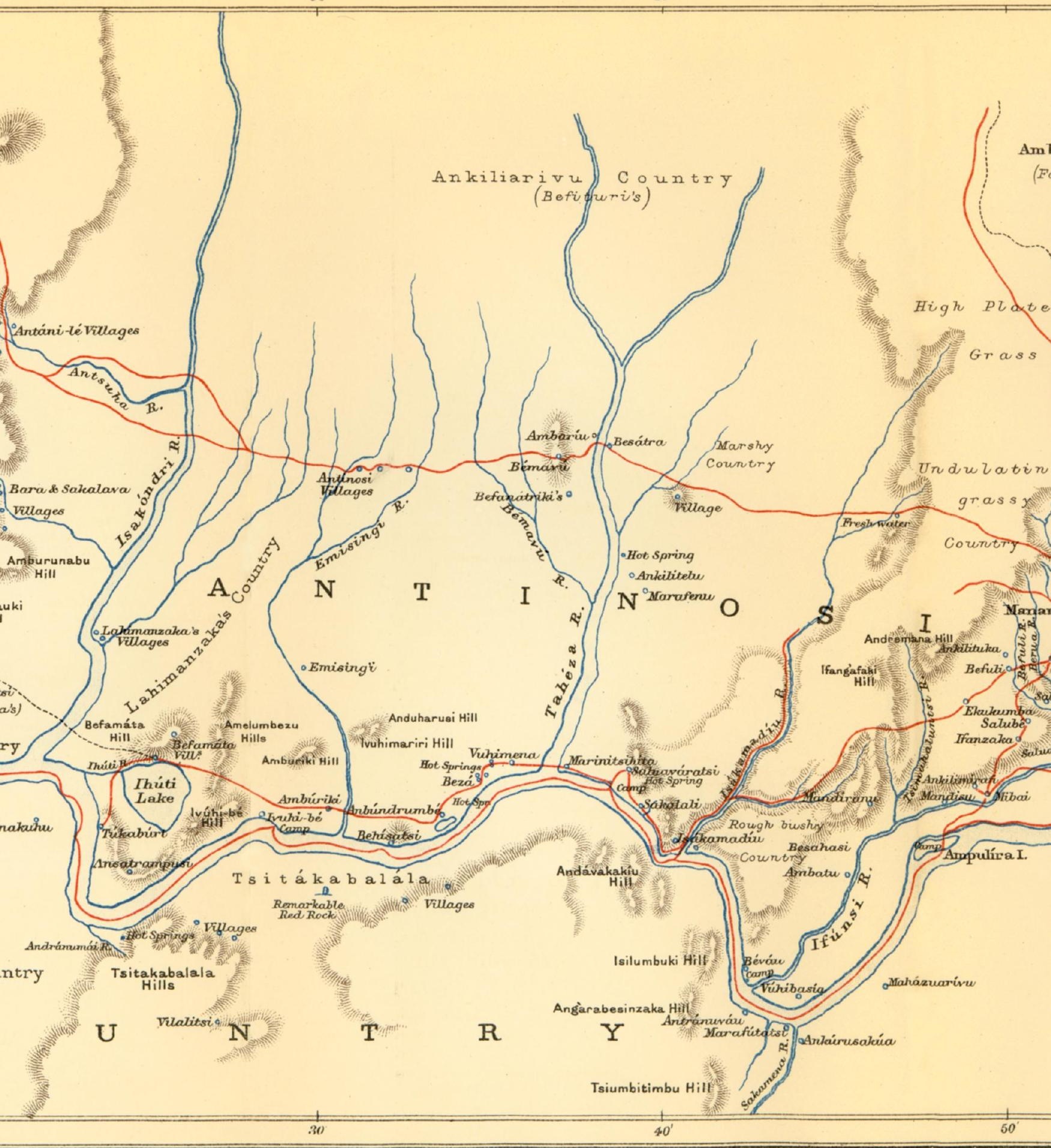

d by the Royal Geographical Society. 


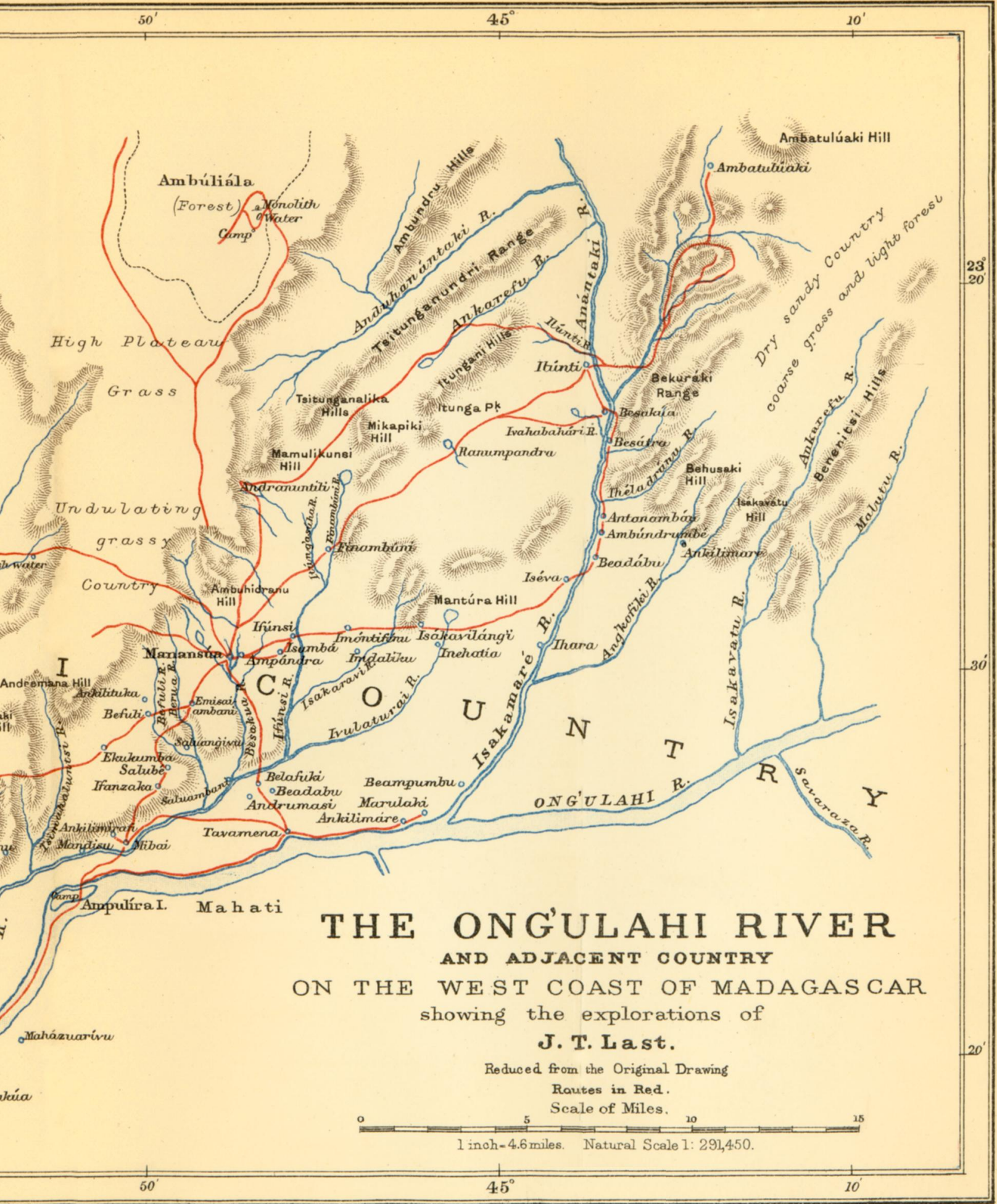


PARTS OF THE WEST COAST

oF

MADAGAS CAR

to illustrate the explorations of J.T.Last.

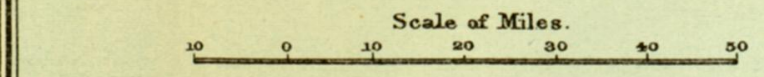

$-1 \pm$
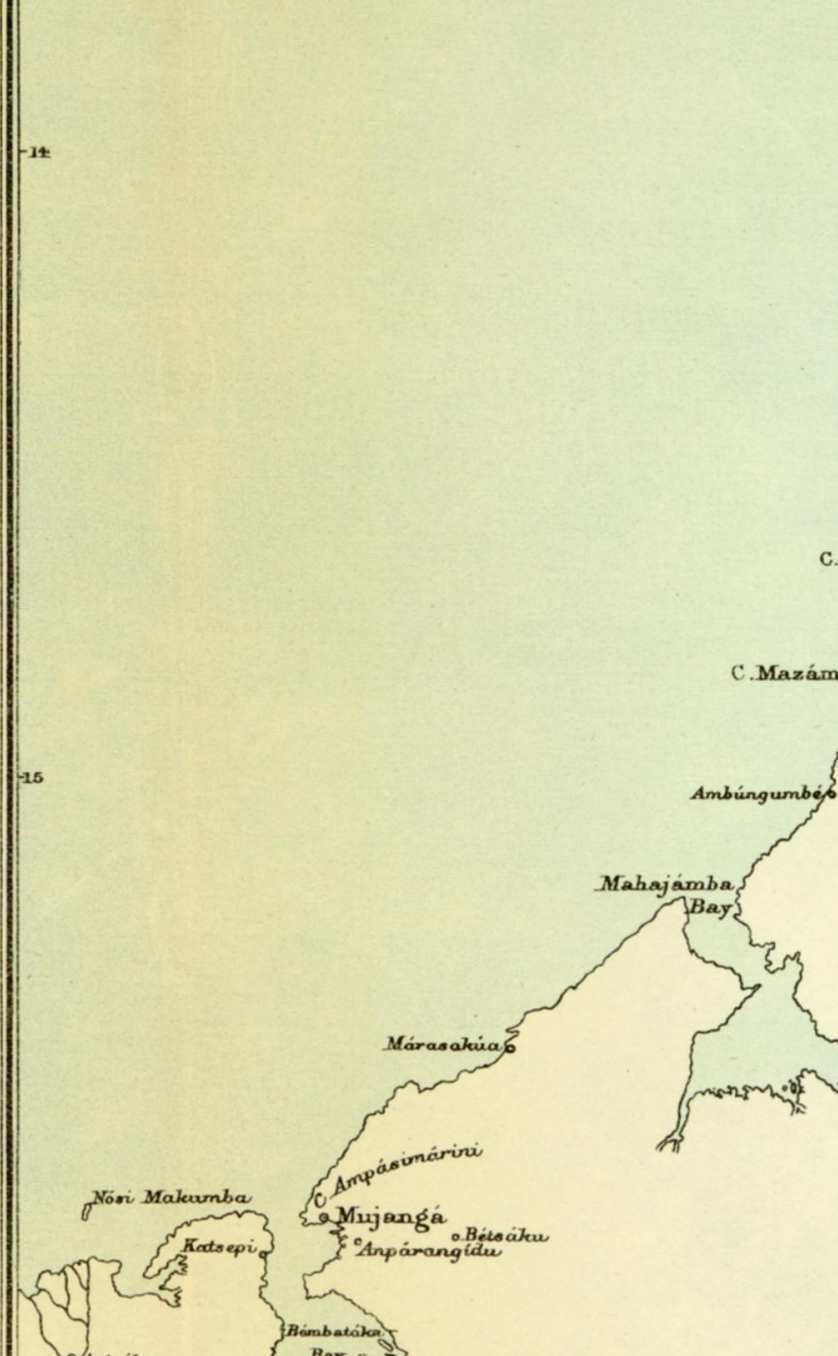

16

efartaniha
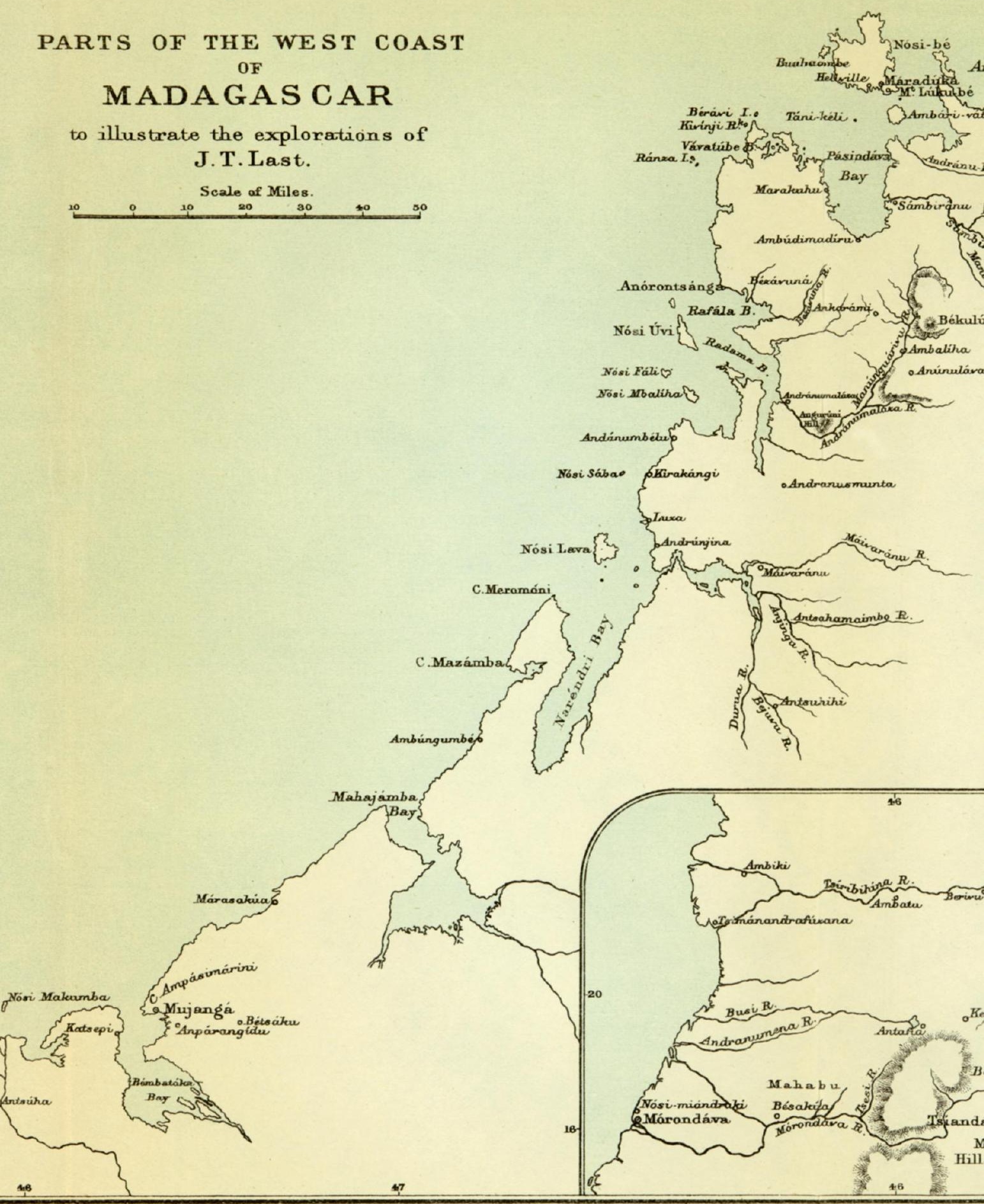


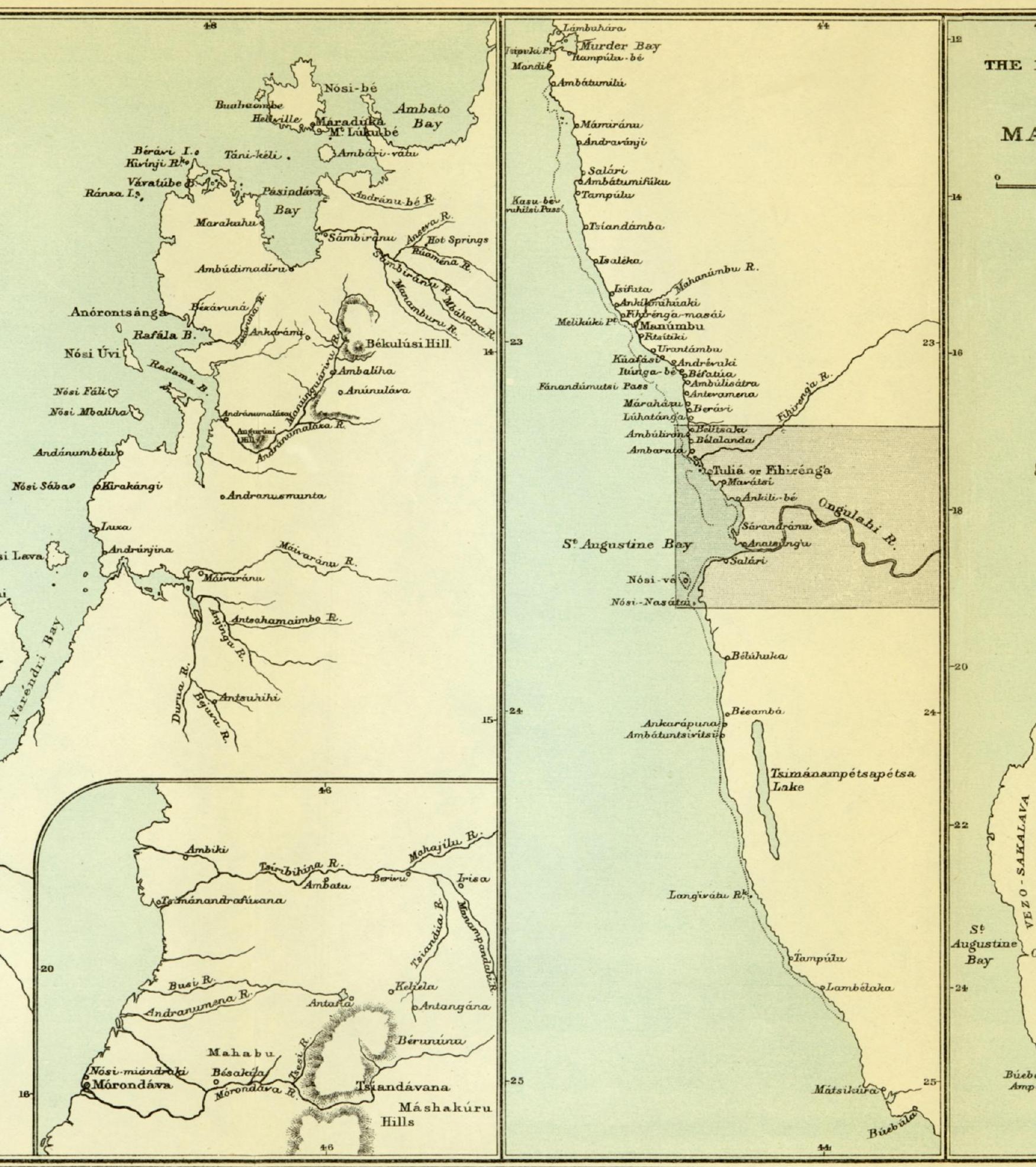

Published by the Royal Geographical Society. 


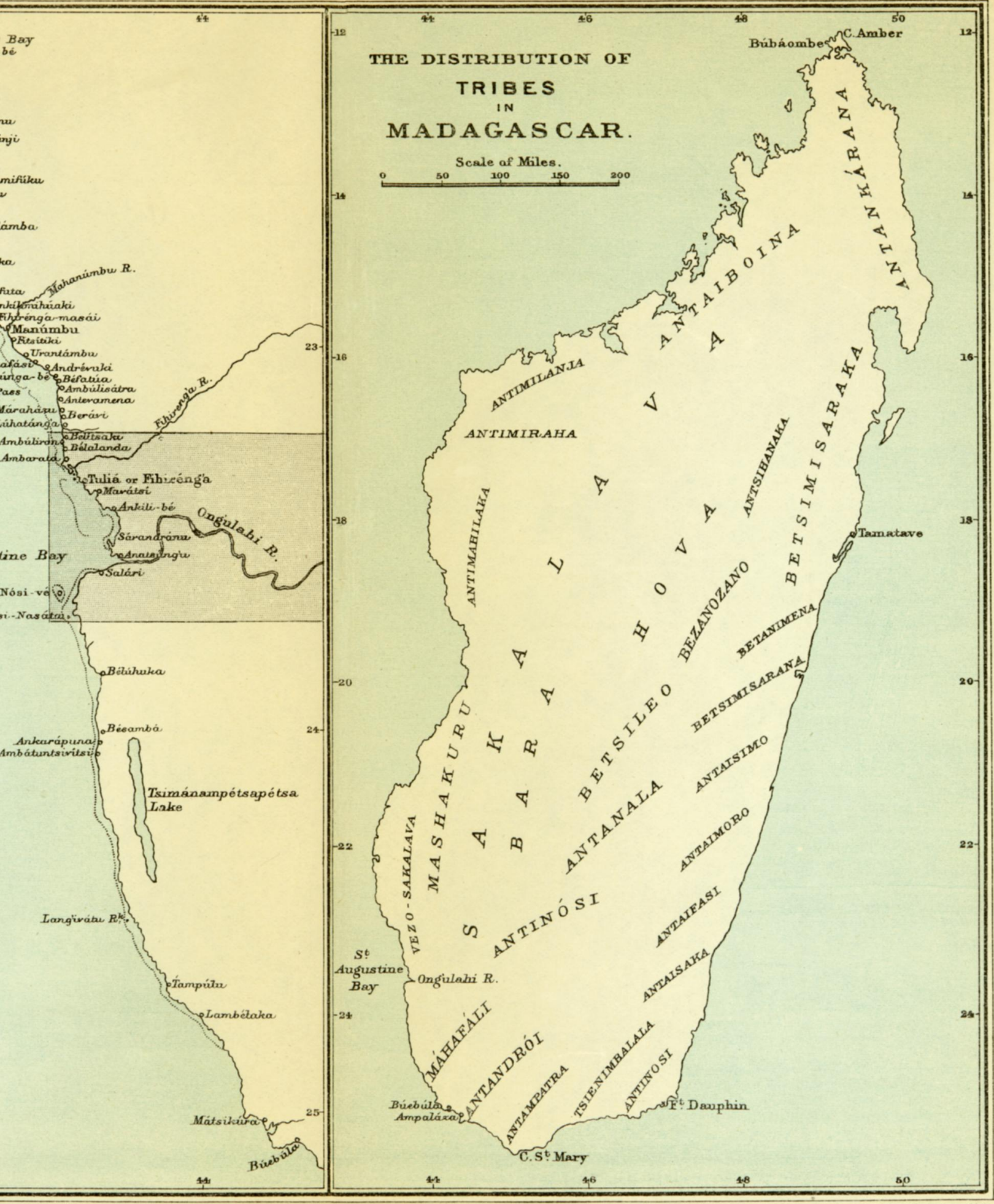

ociety.

F.S.Weller, bith 